Revista Brasil. Bot., V.31, n.4, p.555-558, out.-dez. 2008

\title{
A new species of Utricularia (Lentibulariaceae) from central Brazil
}

\author{
CLAUDIA PETEAN BOVE ${ }^{1}$
}

(received: August 02, 2007; accepted: August 17, 2008)

\begin{abstract}
A new species of Utricularia (Lentibulariaceae) from central Brazil). Utricularia cochleata C. P. Bove (Lentibulariaceae) from the "cerrado" (savanna) in central Brazil is described and illustrated. It is similar to Utricularia aureomaculata Steyerm. and Utricularia steyermarkii P. Taylor and can be distinguished from both by the densely branched traps, smaller lower calyx lobe, with rounded apex, the spur longer than the lower lip, insertion of the thecae below the filament apex, and the ciliate stigma.
\end{abstract}

Key words - "cerrado", hydrophyte, insetivorous, taxonomy, Utricularia

RESUMO - (Uma nova espécie de Utricularia (Lentibulariaceae) do Brasil central). Utricularia cochleata C. P. Bove (Lentibulariaceae) do cerrado no Brasil Central é descrita e ilustrada. É semelhante a Utricularia aureomaculata Steyerm. e Utricularia steyermarkii P. Taylor e se distingue destas espécies pelos utrículos densamente ramificados, lobo inferior do cálice menor e arredondado, cálcar excedendo a corola, inserção da teca subterminal e estigma ciliado.

Palavras-chave - cerrado, hidrófita, insetívora, taxonomia, Utricularia

\section{Introduction}

Utricularia L. (Lentibulariaceae) is an insectivorous, hydrophyllous genus comprising over 200 species of worldwide distribution, except in some oceanic islands and arid regions. In Brazil there are 58 species recorded from different aquatic or moist habitats. A total of 35 species occur in "cerrado". They occur on damp sandy soil in open grassland, streams and pool sides or seasonally flooded grassland. Two species are found on mossy rocks: Utricularia pubescens Sm., with a broad geographical distribution and occurring in a wide range of habitats, and $U$. longifolia Gardn., a Neotropical species recorded only on wet rocks with Sphagnum (Taylor 1989). The new species described here was collected on rocks with Riccardia S. Gray (Aneuraceae, Hepatophyta), Plagiochila (Dum.) Dum. (Plagiochilaceae, Hepatophyta) and Sematophyllum Mitt. (Sematophyllaceae, Bryophyta) in the spray of a waterfall in central Brazil, a very specialized habitat.

\section{Results}

Utricularia cochleata C.P. Bove sp. nov. Type: BRAZIL. Goiás: Serranópolis, road GO-184, km 30, Ponte de Pedra, Cachoeira Felicidade, $18^{\circ} 8^{\prime} 13.5^{\prime \prime} \mathrm{S}$; 51 ${ }^{\circ} 34^{\prime} 52^{\prime \prime} \mathrm{W}$, Rio Claro drainage, Rio Paraná basin, on mossy rocks in

\footnotetext{
1. Museu Nacional (UFRJ), Departamento de Botânica, Quinta da Boa Vista, São Cristóvão, 20940-040 Rio de Janeiro, RJ, Brazil.

2. Autor para correspondência: cpbove@ hotmail.com
}

waterfall spray. fl. 17-I-2004, C.P. Bove, W.J.E.M. da Costa \& B.B. Costa 1334 (holotype R, isotype SP).

Figure 1

Species nova ad U. aureomaculata Steyerm. et U. steyermarkii P. Taylor affinis sed utriculis dense ramosis, lobis calyces subaequalibus apice rotundato, calcare paullo maiori quam labium infernum, antheris parte subterminali filamenti dispositis et stigmate ciliato ab ambabus recedit.

Small, delicate, bryophyllous lithophyte. Rhizoids apparently absent or few (3-5), filiform, terete, tapering from $c a$. $0.36 \mathrm{~mm}$ thick at base to less than $0.1 \mathrm{~mm}$ at apex. Stolons numerous and mat-forming with bryophytes, capillary, branched, $0.08-0.12 \mathrm{~mm}$ thick, internodes $5 \mathrm{~mm}$ long. Leaves numerous on stolons, long-petiolate (1.0$1.5 \mathrm{~cm}$ ), polymorphic; lamina obovate to linear or narrowly elliptic, smaller laminae numerous, 1 -nerved, $5 \times 1 \mathrm{~mm}$, membranous, with rounded apex, greater laminae few, $40 \times 5 \mathrm{~mm}$, somewhat fleshy, venation semicraspedodromous, apex acute to rounded, some leaves with intermediate forms, apex rarely shortly bifurcated or constricted centrally. Traps numerous on stolons, rarely on leaf petioles, ovoid, stalked, 0.5-1.7 mm long, 0.5-1.1 mm wide, mouth lateral with two dorsal, setiform, branched appendages; all vegetative parts covered with unicellular, capitate, short-stalked trichomes (10-16 $\mu \mathrm{m}$ diam.), larger and more densely distributed on ventral side of trap. Inflorescence erect, solitary, simple, $6-7.5 \mathrm{~cm}$ long, peduncle filiform, terete, $0.5 \mathrm{~mm}$, glabrous. Scales few (2-3), equally spaced on peduncle, basisolute, attached near middle, amplexicaule. Bracts basisolute, similar to 


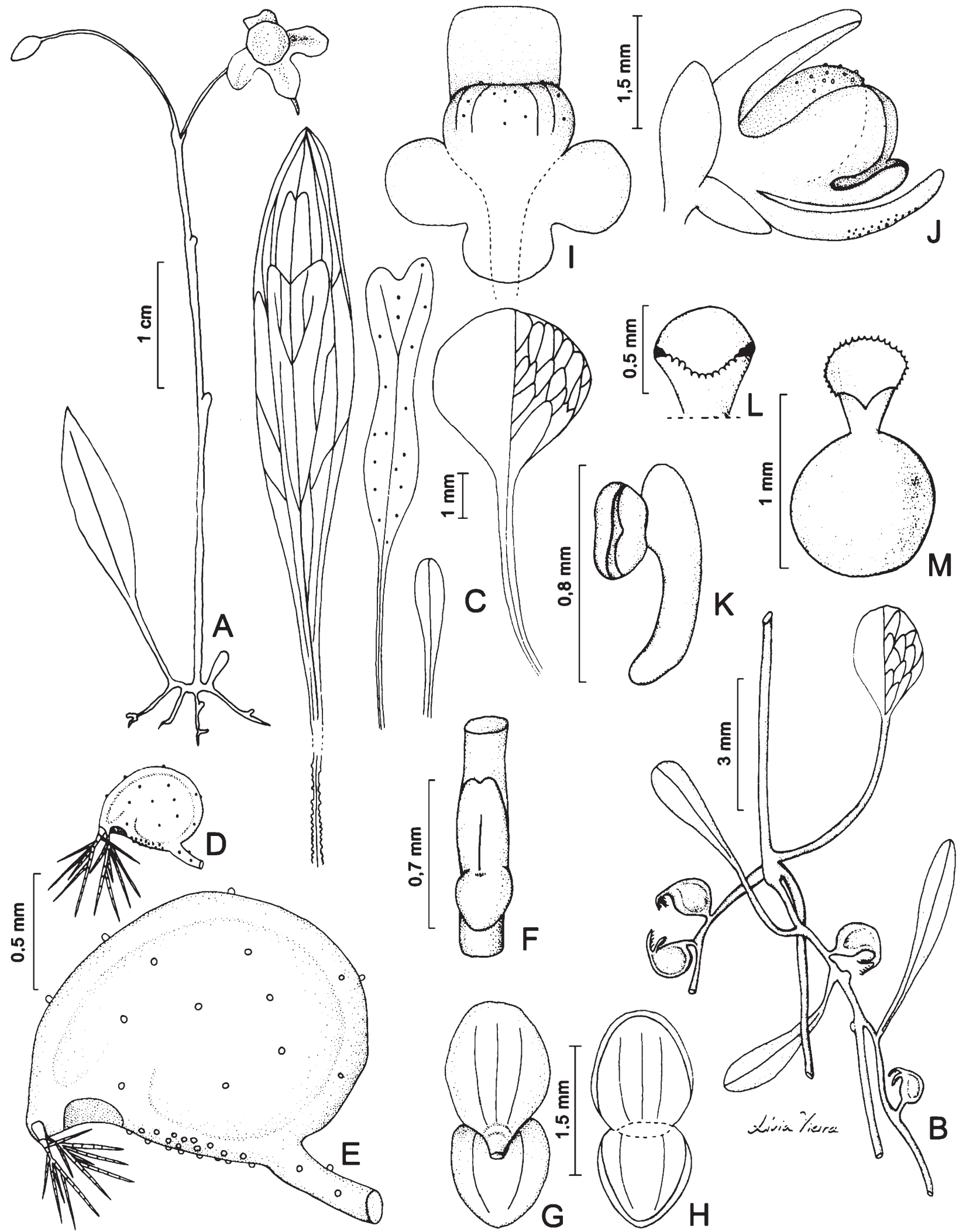

Figure 1. Utricularia cochleata (Bove et al. 1334). A. Habit. B. Base of plant with rhizoids, stolons, leaves, traps and peduncle base. C. Leaves of varying form. D. Immature trap. E. Mature trap. F. Bract. G. Calyx, anterior view. H. Calyx, posterior view. I. Flower, anterior view. J. Preanthesal flower, lateral view. K. Stamen. L. Closed pistil. M. Opened pistil. 
scales, ovate, $0.7 \mathrm{~mm}$ long, superior apex acute, inferior apex rounded; bracteoles absent. Flowers 1-3, raceme axis elongate, flexuous; pedicels ascending, capillary, terete, $10.0 \mathrm{~mm}$ long, $0.35 \mathrm{~mm}$ diam. Calyx lobes slightly unequal; upper lobe circular, convex, apex rounded, 1.2 $\times 1.4 \mathrm{~mm}, 3$-nerved, nerves not reaching margin, somewhat indistinct; lower lobe slightly smaller, circular, convex, apex rounded, $0.8 \times 1.2 \mathrm{~mm}$, 2-nerved, nerves not reaching margin, somewhat indistinct. Corolla $3 \mathrm{~mm}$ long, deep yellow; upper lip obovate-oblong, sides straight and almost parallel, apex truncate or slightly trilobed; lower lip limb approximately circular in outline, the base with a prominent swelling, apex deeply trilobed; spur narrowly cylindrical from a conical base, apex acute, slightly longer than lower lip, with internal glands on ventral surface, except in the apex. Filaments almost straight, $0.8 \mathrm{~mm}$ long, anther thecae indistinct, inserted below filament apex, confluent; pollen grains small $(18 \mu \mathrm{m})$, spherical, 8-11 colporate, longicolpate, endocingulate, microreticulate. Ovary globose $(0.75 \mathrm{~mm})$; style short; stigma lower lip semicircular, shortly ciliate, upper lip obsolete, ovules with reticulate integument. Fruit unknown.

Paratypes: BRAZIL. GoIÁs: Serranópolis, estrada GO-184, Km 30. Ponte de Pedra. Cachoeira Felicidade, 1808'13.5” S; 51³4'52” W, st. 11-IV-2006, C.P. Bove, W.J.E.M. da Costa \& J. Paz 1639 (R); fl. 11-I-2007, C.P. Bove, W.J.E.M. da Costa \& B.B. Costa 1813 (R).

Distribution and habitat: known only from the type locality. It grows on mossy rocks under permanent spray of a waterfall.

Etymology: from the Latin cochleatus (a, um) in reference to the recurved corolla that resembles a shell (figure 1), an adjective.

\section{Discussion}

Although Utricularia cochleata C. P. Bove lives on rocks, it depends on the presence of bryophyte mats to create the adequate humid microhabitat. This raises the question in to which ecological classification it fits best: lithophytes or epiphytes? A gradual transition from lithophytes to epiphytes is seen in sections Choristhecae P. Taylor, Mirabilis P. Taylor, Phyllaria (Kurz) Kamiénski and Steyermarkia P. Taylor. All are small plants with a simple and expanded leaf lamina, known only from northern South America (Venezuela, Surinam, French Guiana) and Tropical Asia (Utricularia. sect. Phyllaria) (Taylor 1989).

Utricularia cochleata is here considered a member of the subgenus Utricularia P. Taylor (two lobed calyx), section Steyermarkia, due to the simple and multinerved leaves, basisolute bracts, bracteoles always absent, the lower calyx lobe smaller than the upper, and the yellow corolla with the lower lip trilobed. The great variation of leaf form resembles $U$. aureomaculata Steyerm. and $U$. steyermarkii $\mathrm{P}$. Taylor, but $U$. cochleata differs from both in the densely branched traps, smaller lower calyx lobe, with rounded apex, the spur longer than the lower lip, the insertion of the thecae below the filaments apex, and the ciliate stigma (table 1). This is the first record of section Steyermarkia for the "cerrado" and for the central region of Brazil.

Acknowledgements - I am especially grateful to Dr. Thomas Philbrick of the Western Connecticut State University (USA), Wilson Costa of the Universidade Federal do Rio de Janeiro (Brazil) and two anonymous reviewers for comments on the manuscript, to Dra. Andréa Luizi-Ponzo of the Universidade Federal de Juiz de Fora (Brazil) for the identification of the

Table 1. Comparison of distinctive characters of species of Utricularia section Steyermarkia.

\begin{tabular}{|c|c|c|c|}
\hline Character & U. cochelata C.P. Bove & U. aureomaculata Steyerm & U. steyermarkii $\mathrm{P}$. Taylor \\
\hline Traps & densely branched (6-8) & sparsely branched (2-3) & sparsely branched (2-3) \\
\hline $\begin{array}{l}\text { Calyx lower } \\
\text { lobe size }\end{array}$ & $\begin{array}{l}\text { slightly smaller than the } \\
\text { upper lobe }\end{array}$ & $\begin{array}{l}\text { very much smaller than } \\
\text { the upper lobe }\end{array}$ & $\begin{array}{l}\text { much smaller than the } \\
\text { upper lobe }\end{array}$ \\
\hline $\begin{array}{l}\text { Calyx lower } \\
\text { lobe apex }\end{array}$ & round & emarginate & truncate or retuse \\
\hline Spur & longer than the lower lip & shorter than the lower lip & shorter than the lower lip \\
\hline Thecae insertion & $\begin{array}{l}\text { below the apex of the } \\
\text { filaments }\end{array}$ & at the apex of the filaments & at the apex of the filaments \\
\hline Stigma & ciliate & not ciliate & not ciliate \\
\hline
\end{tabular}


Hepatophyta and Bryophyta, and to Dr. Pedro Carauta for the Latin description. I thank Lívia Vieira for line drawings based on the author's original drawings and Adriana Oliveira for aid on the plate. Field work could not have been conducted without the valuable assistance of Wilson Costa and Bruno Costa.

\section{References}

TAYLOR, P. 1989. The genus Utricularia - a taxonomic monograph. Kew Bulletin Additional series XIV. HMSO, London. 